\title{
Zinc Binding to Lambda Phage DNA Studied by Voltammetric Techniques
}

\author{
Jurandir R. de Souza*, Clarissa S. P. de Castro and Carlos Bloch Jr. \\ Instituto de Química, Universidade de Brasília, CP 04394, 70.919-970, Brasília - DF, Brazil
}

\begin{abstract}
A interação do zinco com o DNA do fago $\lambda$ foi investigada utilizando a voltametria de pulso diferencial e a voltametria cíclica. Os métodos baseiam-se no monitoramento direto da corrente de redução e oxidação do zinco na ausência e na presença do DNA viral. Curvas de titulação do Zn ${ }^{2+}$ com o DNA do fago $\lambda$ foram obtidas nos intervalos de concentração 3,57 x 10-12 a 3,92 x 10-11 mol L ${ }^{-1}$ e 6,97 x $10^{-12}$ a $5,56 \times 10^{-11} \mathrm{~mol} \mathrm{~L}^{-1}$. Estes dados foram utilizados para o cálculo da constante de dissociação do complexo e da estequiometria. O mecanismo da reação foi estudado utilizando a voltametria cíclica. Curvas do tipo I (corrente de oxidação do zinco) versus v1/2 (raiz quadrada da velocidade de varredura) mostraram que o processo oxidação-redução do zinco deixa de ser difusional na presença do DNA do fago $\lambda$.
\end{abstract}

Binding of zinc to lambda phage DNA was investigated by differential pulse voltammetry and cyclic voltammetry. These methods rely on the direct monitoring of reduction and oxidation current of zinc in the absence and presence of this virion DNA. Titration graphs of $\mathrm{Zn}^{2+}$ with DNA were obtained in the concentration ranges from $3.57 \times 10^{-12}$ to $3.92 \times 10^{-11} \mathrm{~mol} \mathrm{~L}^{-1}$ and $6.97 \times 10^{-12}$ to $5.56 \times 10^{-11} \mathrm{~mol} \mathrm{~L}^{-1}$. These data were used to calculate the dissociation constant of the complex and the stoichiometry. The mechanism of this reaction was studied by cyclic voltammetry through curves I (oxidation current of $\mathrm{Zn}^{2+}$ ) versus $\mathrm{v}^{1 / 2}$ (square root of scan rate). These curves showed that the oxidation-reduction process of $\mathrm{Zn}^{2+}$ was not controlled by diffusion in the presence of lambda phage DNA.

Keywords: differential pulse voltammetry, cyclic voltammetry, zinc, lambda phage DNA

\section{Introduction}

Nucleic acids, which play critical roles in living organisms in the storage, transmission, and expression of genetic information, are actually salts of metal ions. Interest in metal-nucleic acid interactions is based on the involvement of metal ions $\left(\mathrm{Zn}^{2+}, \mathrm{Mg}^{2+}, \mathrm{Mn}^{2+}\right)$ in nucleic acid biosynthesis, processing, and degradation, as well as information transfer and expression, mutagenesis, chromosomal abnormalities, and carcinogenesis. Unfortunately, it is often difficult to determine the actual molecular mechanism responsible for the observed effects, since many intracellular species, in particular some proteins, can act as mediators between the metal ion and nucleic acid in vivo. Before such complex systems can be understood, binding and conformation effects of the components have to be analyzed ${ }^{1,2}$.

Presented at the XI Simpósio Brasileiro de Eletroquímica e Eletroanalítica, Maragogi - AL, Brazil, April 5-9, 1999. Guest editor: Luis Alberto Avaca.
Metal-ion binding to nucleic acid has been studied by several techniques including conductimetry ${ }^{3-5}\left(\mathrm{Mg}^{2+}\right.$ DNA, Ca ${ }^{2+}$-DNA), UV-Vis spectroscopy ${ }^{5-16}\left(\mathrm{Mg}^{2+}-\mathrm{DNA}\right.$, $\mathrm{Ca}^{2+}$-DNA, $\mathrm{Cu}^{2+}$-DNA, $\mathrm{Mn}^{2+}-\mathrm{DNA}, \mathrm{Ni}^{2+}-\mathrm{DNA}, \mathrm{Cd}^{2+}$ DNA, $\mathrm{Hg}^{2+}$-DNA, $\mathrm{Cr}^{3+}-\mathrm{DNA}, \mathrm{Zn}^{2+}-\mathrm{DNA}$ ), equilibrium dialysis ${ }^{17-19}\left(\mathrm{Mg}^{2+}-\mathrm{DNA}, \mathrm{Ca}^{2+}-\mathrm{DNA}, \mathrm{Co}^{2+}-\mathrm{DNA}, \mathrm{Zn}^{2+}\right.$ DNA) and X-ray crystallography ${ }^{20-23}\left(\mathrm{Ca}^{2+}-\mathrm{DNA}, \mathrm{Mg}^{2+}\right.$ DNA, $\mathrm{Na}^{+}$-DNA, $\mathrm{Li}^{+}$-DNA). However, all these techniques present considerable experimental difficulties or limitations. In conductivity experiments a problem arises because the contribution of the partially complexed macromolecules to the conductivity is neither negligible nor constant. The utilization of UV-Vis spectroscopy is difficult in general because many metal complexes show small changes in molar absorptivity on binding to $\mathrm{DNA}^{24}$. Dialysis experiments reach equilibrium only in solutions of high ionic strength and at this condition the small monovalent cations which are commonly used compete with divalent ions for binding sites, making it difficult to measure the divalent ion binding at low concentration. In X-ray crystallography studies it has been found that, in many cases, the 
conformation of nucleic acids in crystals and in solution are not identical because there are more intermolecular interactions in a solid phase than in dilute solution ${ }^{21-23}$. The electrochemical methods have been reported to have several advantages in these measurements, e.g., applicability in determining the strength of binding of the complex and the size of binding site (i.e., number of base pairs) by studying the voltammetry of the complex in the absence and presence of DNA and noting shifts in standard potential caused by the interaction ${ }^{15,25-27}$.

In this work, an attempt was made to determine and analyze the complex formation of lambda phage DNA with zinc by using differential pulse voltammetry and cyclic voltammetry. Lambda phage is a bacterial virus composed by a protein capsid divided into an icosahedrally symmetric head that contains a DNA genome and a flexible helical tail that plays a role in attaching to the specific host bacterium (E. coli) and injecting DNA. The lambda genome is a linear double-stranded DNA molecule having almost 50.000 base pairs (bp) with 12 bp single-stranded complementary 5' -ends (sticky ends). It is a common substrate for restriction endonucleases and for generating DNA size markers fragments.

This study was motivated by the thought that useful and interesting information concerning the structure and properties of the nucleic acids can be obtained by investigation of their metal ion complexes. Particularly, our interest is focused on the cleavage of DNA which is an important biological process because, through the DNA fragments produced, it is possible to manipulate and map genes and also identify some specific viruses and parasite groups. Zinc is an important regulatory element in the cleavage of DNA, but details of its chemical interaction with DNA and nucleases and its potential role in the ligand binding process are not well characterized.

\section{Experimental}

\section{Chemicals}

Lambda phage DNA was purchased from Sigma Chemical Co. It had been isolated from Escherichia coli Host Strain W3110 and had a high molecular weight $\mathrm{MM}=3.2$ $\mathrm{x} 10^{7} \mathrm{~g} \mathrm{~mol}^{-1}$. All other chemicals were reagent grade (Aldrich) and all solutions were prepared with triply- distilled water from a quartz still (Quartex).

\section{Apparatus}

Differential pulse polarographic (DPP) measurements were carried out on a 646 Metrohm Voltammetric Analyzer Processor connected to a 647 Metrohm electrochemical cell composed of a dropping mercury electrode (working electrode), an $\mathrm{Ag} / \mathrm{AgCl}\left(\mathrm{KCl} 3.0 \mathrm{~mol} \mathrm{~L}^{-1}\right.$ ) electrode (reference electrode) and a platinum electrode (auxiliary electrode). All DPP measurements were performed in the potential range $0.18 \mathrm{~V}$ (initial potential, $\mathrm{E}_{\mathrm{i}}$ ) to $-1.15 \mathrm{~V}$ (final potential, $\mathrm{E}_{\mathrm{f}}$ ) at the following settings: surface area of the mercury drop $0.4 \mathrm{~mm}^{2}$, pulse amplitude $50 \mathrm{mV}$ and the scan rate $\mathrm{v}=10 \mathrm{mV} \mathrm{s}^{-1}$.

Cyclic voltammetric (CV) measurements were performed using a PAR 173 Potentiostat/Galvanostat connected to a PAR 175 Universal Programmer and a Houston $\mathrm{X}-\mathrm{Y}$ recorder at the following settings: initial potential $\mathrm{E}_{\mathrm{i}}$ $=-0.2 \mathrm{~V}$, switching potential $\mathrm{E}_{\mathrm{W}}=-1.6 \mathrm{~V}$ and scan rate range $2 \mathrm{mV} \mathrm{s}^{-1} \leq \mathrm{v} \leq 50 \mathrm{mV} \mathrm{s}^{-1}$. A three electrode system with a hanging mercury electrode (Metrohm) as working electrode, an $\mathrm{Ag} / \mathrm{AgCl}\left(\mathrm{KCl} 4.0 \mathrm{~mol} \mathrm{~L}^{-1}\right)$ electrode as reference electrode and a platinum wire as the auxiliary electrode were used.

\section{Procedure}

Prior to voltammetric measurements, lambda phage DNA was exhaustively dialyzed against $0.1 \mathrm{~mol} \mathrm{~L}^{-1}$ EDTA to remove zinc and other metals and then further dialyzed against quartex water to remove all the EDTA and other salts. The concentration of lambda phage DNA was determined by UV measurements at $260 \mathrm{~nm}$ through the expression $1.0 \mathrm{~A}_{260 \mathrm{~nm}}$ DS DNA $=50 \mu \mathrm{g} / \mathrm{ml}^{28}$. The purity (freedom from bound protein) was assessed from the ratio of the absorbances at 260 and $280 \mathrm{~nm}^{28}$.

In order to avoid measurement interference due to DNA and zinc adsorption on the working surfaces of the electrode system, electrodes were submitted to periodic cleaning with $\mathrm{HNO}_{3} 20 \%(\mathrm{v} / \mathrm{v})$ followed by a generous wash with triply-distilled water. All experiments were performed at room temperature and preceded by a gentle $\mathrm{N}_{2}$ bubbling to prevent oxygen diffusion into the electrochemical cell (10 minutes for the supporting electrolyte $-\mathrm{KNO}_{3}$ $0.1 \mathrm{~mol} \mathrm{~L}^{-1}$ and 3 minutes after each DNA addition).

The amperometric titration of $\mathrm{Zn}^{2+}$ with lambda phage DNA by using differential pulse polarography and cyclic voltammetry was accomplished through additions of 5 or $10 \mu \mathrm{L}$ of this virion DNA to the electrochemical cell containing $1.0 \mathrm{~mL}$ of $1.5 \times 10^{-8} \mathrm{~mol} \mathrm{~L}^{-1} \mathrm{Zn}^{2+}$ in $20 \mathrm{~mL}$ of $0.1 \mathrm{~mol} \mathrm{~L}^{-1} \mathrm{KNO}_{3}$ or $1.5 \mathrm{ml}$ of $1.5 \times 10^{-8} \mathrm{~mol} \mathrm{~L}^{-1}$ $\mathrm{Zn}^{2+}$ in $20 \mathrm{~mL}$ of $0.1 \mathrm{~mol} \mathrm{~L}^{-1} \mathrm{KNO}_{3}$, respectively.

The oxidation-reduction process of zinc was studied in the presence and absence of lambda phage DNA by using cyclic voltammetry through curves I (oxidation current of $\mathrm{Zn}^{2+}$ ) vs. $\mathrm{v}^{1 / 2}$ (square root of scan rate). The oxidation current of zinc was measured in the scan rate range 2 $\mathrm{mV} \mathrm{s}^{-1} \leq \mathrm{v} \leq 50 \mathrm{mV} \mathrm{s}^{-1}$ with and without the addition of 
$40 \mu \mathrm{L}$ of $1.5 \times 10^{-8} \mathrm{~mol} \mathrm{~L}^{-1}$ lambda phage DNA to the electrochemical cell containing $1.5 \mathrm{~mL}$ of $1.5 \times 10^{-8} \mathrm{~mol} \mathrm{~L}^{-1}$ $\mathrm{Zn}^{2+}$ in $20 \mathrm{~mL}$ of $0.1 \mathrm{~mol} \mathrm{~L}^{-1} \mathrm{KNO}_{3}$.

\section{Results}

\section{Differential pulse voltammetry: voltammograms, stoichiometry and dissociation constant}

The addition of lambda phage DNA to a solution of $\mathrm{Zn}^{2+}$ (depolarizer) brings about a decrease in the diffusion current. The relative reduction in this current increases with DNA concentration and with its ratio to the concentration of the zinc. It decreases with increase in ionic strength which is maintained by the concentration of the supporting electrolyte ${ }^{26}$. The differential pulse voltammograms presented in Figure 1 show the dependence of the diffusion current at constant $\mathrm{Zn}^{2+}$ concentration on the concentration of added lambda phage DNA. Curve 1 (Figure 1) represents the reduction of $1.0 \mathrm{~mL}$ of $1.5 \times 10^{-8}$ mol L-1 $\mathrm{Zn}^{2+}$ in $20 \mathrm{~mL}$ of $0.1 \mathrm{~mol} \mathrm{~L}^{-1} \mathrm{KNO}_{3}$. Curves numbered 2-6 (Figure 1) represent the effect of the addition of $7.1 \times 10^{-12}, 1.4 \times 10^{-11}, 2.1 \times 10^{-11}, 2.9 \times 10^{-11}$ and $3.6 \times$ $10^{-11} \mathrm{~mol} \mathrm{~L}^{-1}$ DNA to the electrochemical cell. The resulting changes in reduction current attest to the interaction between $\mathrm{Zn}^{2+}$ and lambda phage DNA.

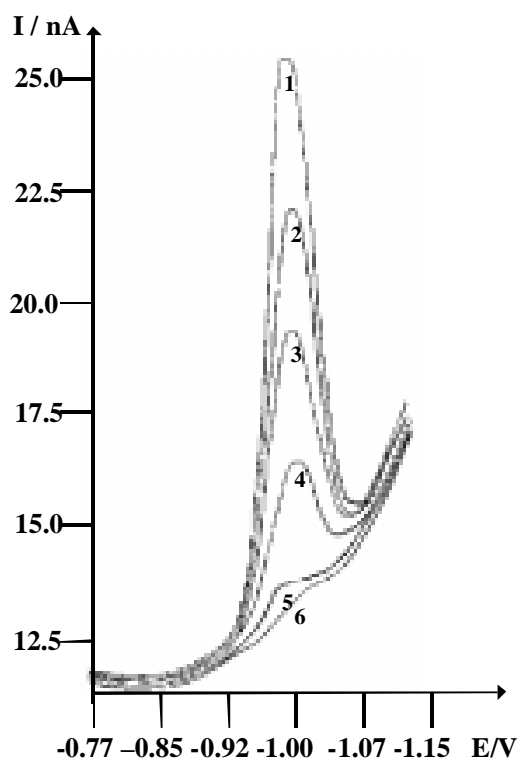

Figure 1. Differential pulse voltammograms of $1.0 \mathrm{~mL}$ of $1.5 \mathrm{x}$ $10^{-8} \mathrm{~mol} \mathrm{~L}^{-1} \mathrm{Zn}^{2+}$ in $20 \mathrm{~mL}$ of $0.1 \mathrm{~mol} \mathrm{~L}^{-1} \mathrm{KNO}_{3}$ with different concentrations of lambda phage DNA. (1) $\mathrm{Zn}^{2+}$, no lambda phage DNA; (2) $\mathrm{Zn}^{2+}+7.1 \times 10^{-12} \mathrm{~mol} \mathrm{~L}^{-1}$ lambda phage DNA; (3) $\mathrm{Zn}^{2+}$ $+1.4 \times 10^{-11} \mathrm{~mol} \mathrm{~L}^{-1}$ lambda phage DNA; (4) $\mathrm{Zn}^{2+}+2.1 \times 10^{-11}$ mol L-1 lambda phage DNA; (5) $\mathrm{Zn}^{2+}+2.9 \times 10^{-11} \mathrm{~mol} \mathrm{~L}^{-1}$ lambda phage DNA; (6) $\mathrm{Zn}^{2+}+3.6 \times 10^{-11} \mathrm{~mol} \mathrm{~L}^{-1}$ lambda phage DNA. $\mathrm{E}_{\mathrm{i}}=0.180 \mathrm{~V}, \mathrm{E}_{\mathrm{f}}=-1.15 \mathrm{~V}$, pulse amplitude $=50 \mathrm{mV}$, scan rate $=10$ $\mathrm{mV} \mathrm{s}^{-1}$, working electrode: DME.
The amperometric titration curve of zinc with lambda phage DNA is shown in Figure 2. We found a complete decrease in the reduction current of $\mathrm{Zn}^{2+}$ after the addition of $43 \mu \mathrm{L}$ of DNA to the electrochemical cell. This volume of lambda phage DNA used in the complexation of zinc was determined through the inflection point (I.P.) of the titration curve and was employed to calculate the stoichiometry of the reaction. By this method, we found one lambda phage DNA per $23 \mathrm{Zn}^{2+}$ ions.

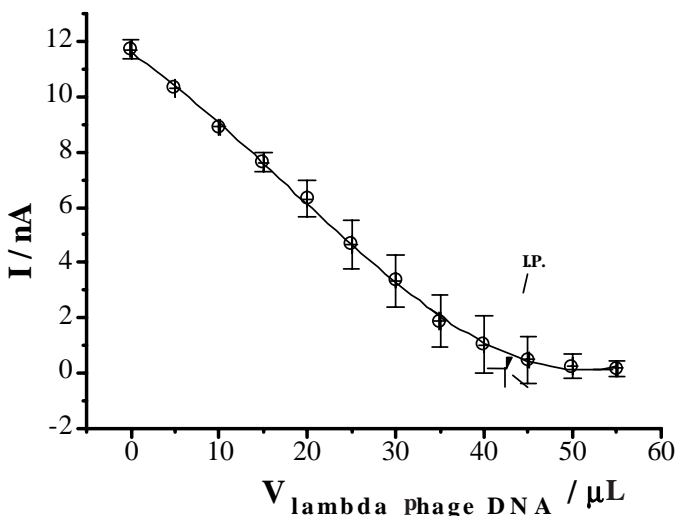

Figure 2. Amperometric titration Graph of $1.0 \mathrm{~mL}$ of $1.5 \times 10^{-8}$ mol L-1 $\mathrm{Zn}^{2+}$ in $20 \mathrm{~mL}$ of $0.1 \mathrm{~mol} \mathrm{~L}^{-1} \mathrm{KNO}_{3}$ with lambda phage DNA. Successive additions of $5.0 \mu \mathrm{L}$ of $1.5 \times 10^{-8} \mathrm{~mol} \mathrm{~L}^{-1}$ lambda phage DNA solution were made.

For a complex of the electro-active substance $\mathrm{Zn}^{2+}$ with lambda phage DNA, the electrochemical reduction reactions can be divided in two steps:

$\mathrm{Zn}^{2+}-\mathrm{DNA} \rightleftharpoons \mathrm{Zn}^{2+}+\mathrm{DNA}$

$\mathrm{Zn}^{2+}+2 \mathrm{e}^{-} \rightleftharpoons \mathrm{Zn}^{0}$

The dissociation constant $\left(\mathrm{K}_{\mathrm{d}}\right)$ of the $\mathrm{Zn}^{2+}$-Lambda Phage DNA complex was obtained using the following equation $^{29}$ :

$i_{p}^{2}=\frac{k_{d}}{[D N A]}\left(i_{p 0}^{2}-i_{p}^{2}\right)+i_{p 0}^{2}-[D N A]$

where: $\mathrm{K}_{\mathrm{d}}=$ dissociation constant of the complex $\mathrm{Zn}^{2+}$. Lambda Phage DNA; $\mathrm{i}_{\mathrm{p} 0}{ }^{2}=$ reduction current of $\mathrm{Zn}^{2+}$ in the absence of lambda phage DNA; $i_{p}{ }^{2}=$ reduction current of $\mathrm{Zn}^{2+}$ in the presence of lambda phage DNA; [DNA $]=$ concentration of added lambda phage DNA in solution.

According to equation (3), $\mathrm{i}_{\mathrm{p} 0}$ and different values of $\mathrm{i}_{\mathrm{p}}$ are determined respectively by holding the concentration of $\mathrm{Zn}^{2+}$ constant and varying the concentration of lambda phage DNA. 
The curve $i_{p}^{2}$ versus $\frac{\left(i_{p 0}^{2}-i_{p}^{2}\right)}{[\text { DNA }]}$ (Figure 3) for the complex $\mathrm{Zn}^{2+}$ - lambda phage DNA was plotted and one straight line was obtained. From the slope, the dissociation constant was determined as $3.44 \times 10^{-11} \mathrm{~mol} \mathrm{~L}^{-1}$.

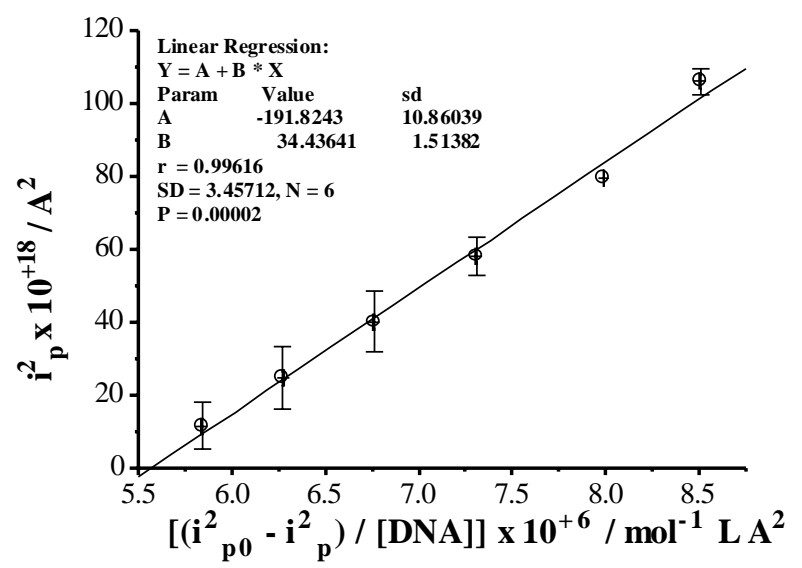

Figure 3. The plot $i_{p}^{2}$ vs. $\frac{\left(i_{p 0}^{2}-\dot{i}_{p}^{2}\right)}{[D N A]}$ used to calculate the dissociation constant of $\mathrm{Zn}^{2+-}$ lambda phage DNA complex.

Cyclic Voltammetry: voltammograms, stoichiometry, dissociation constantandreactionmechanism

The cyclic voltammograms of $1.5 \mathrm{~mL}$ of $1.5 \times 10^{-8}$ mol L-1 $\mathrm{Zn}^{2+}$ in $20 \mathrm{~mL}$ of $0.1 \mathrm{~mol} \mathrm{~L}^{-1} \mathrm{KNO}_{3}$ with different concentrations of lambda phage DNA are shown in Figure 4. Curve 1 (Figure 4) represents the oxidation of zinc in $0.1 \mathrm{~mol} \mathrm{~L}^{-1} \mathrm{KNO}_{3}$. Curves numbered 2, 3 and 4 (Figure 4) show the decrease of the oxidation current of zinc during incremental additions $(20 \mu \mathrm{L})$ of $1.5 \times 10^{-8}$ mol L-1 lambda phage DNA. The resulting changes in this current again demonstrate interaction between $\mathrm{Zn}^{2+}$ and lambda phage DNA.

Figure 5 shows the amperometric titration curve of $\mathrm{Zn}^{2+}$ with lambda phage DNA. The addition of $4.4 \times 10^{-11} \mathrm{~mol} \mathrm{~L}^{-1}$ lambda phage DNA to the electrochemical cell decrease completely the oxidation current of zinc. This volume of lambda phage DNA used in the complexation of zinc was determined through the inflection point (I.P.) of the titration curve and was employed to calculate the stoichiometry of the reaction. By this method, we found one lambda phage DNA per $22 \mathrm{Zn}^{2+}$ ions.

The dissociation constant $\left(\mathrm{K}_{\mathrm{d}}\right)$ of the $\mathrm{Zn}^{2+}$ - lambda phage DNA complex was calculated to be $6.69 \times 10^{-11}$ mol L-1 again using the equation 3 (Figure 6).

The oxidation-reduction process of zinc was investigated through curves I (oxidation current) versus $\mathrm{v}^{1 / 2}$ (square

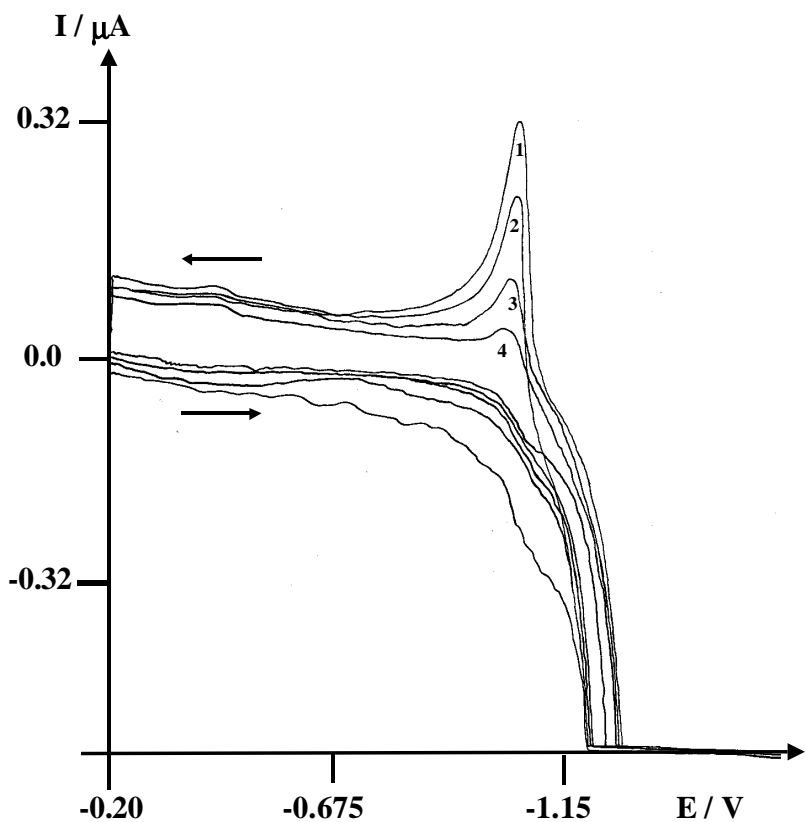

Figure 4. Cyclic voltammograms of $1.5 \mathrm{~mL}$ of $1.5 \times 10^{-8} \mathrm{~mol} \mathrm{~L}^{-1}$ $\mathrm{Zn}^{2+}$ in $20 \mathrm{~mL}$ of $0.1 \mathrm{~mol} \mathrm{~L}^{-1} \mathrm{KNO}_{3}$ with different concentrations of lambda phage DNA. (1) $\mathrm{Zn}^{2+}$, no lambda phage DNA; (2) $\mathrm{Zn}^{2+}+$ $2.8 \times 10^{-11} \mathrm{~mol} \mathrm{~L}^{-1}$ lambda phage DNA; (3) $\mathrm{Zn}^{2+}+4.2 \times 10^{-11}$ mol L-1 lambda phage DNA; (4) $\mathrm{Zn}^{2+}+5.6 \times 10^{-11} \mathrm{~mol} \mathrm{~L}^{-1}$ lambda phage DNA. $\mathrm{E}_{\mathrm{i}}=-0.2 \mathrm{~V}, \mathrm{E}_{\mathrm{w}}=-1.6 \mathrm{~V}$, scan rate $=10 \mathrm{mV} \mathrm{s}^{-1}$, working electrode: HMDE.

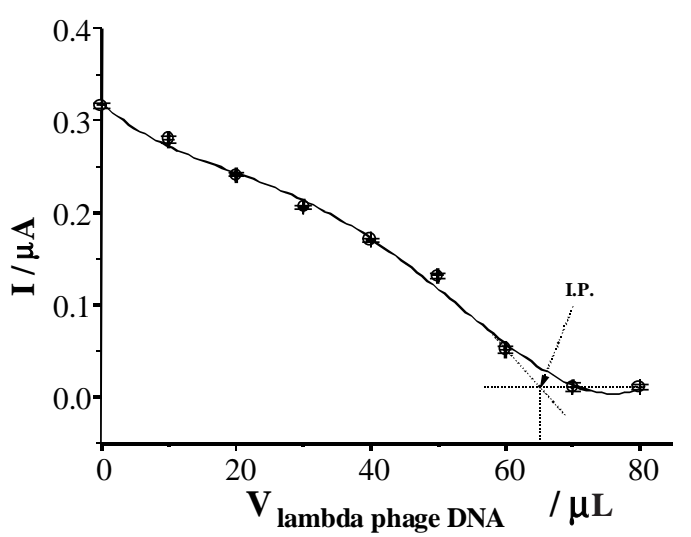

Figure 5. Amperometric titration Graph of $1.5 \mathrm{ml}$ of $1.5 \times 10^{-8}$ mol L-1 $\mathrm{Zn}^{2+}$ in $20 \mathrm{~mL}$ of $0.1 \mathrm{~mol} \mathrm{~L}^{-1} \mathrm{KNO}_{3}$ with lambda phage DNA. Successive additions of fix volume of $10 \mu \mathrm{L}$ of $1.5 \times 10^{-8}$ mol L-1 lambda phage DNA solution.

root of scan rate). As described by the Randles-Sevcik equation $^{30}$, the oxidation current (I) of $\mathrm{Zn}^{2+}$ increases as $\mathrm{v}^{1 / 2}$ in the absence of lambda phage DNA. A plot of this equation yields a straight line, the slope of which can be used to determine the diffusion coefficient of the system (Figure 7, curve $\mathrm{O}$ ). However, in the presence of lambda phage DNA, the electrochemical behavior of $\mathrm{Zn}^{2+}$ changed and its oxidation-reduction process was no longer controlled by diffusion anymore (Figure 7, curve $\mathrm{C}$ ). 


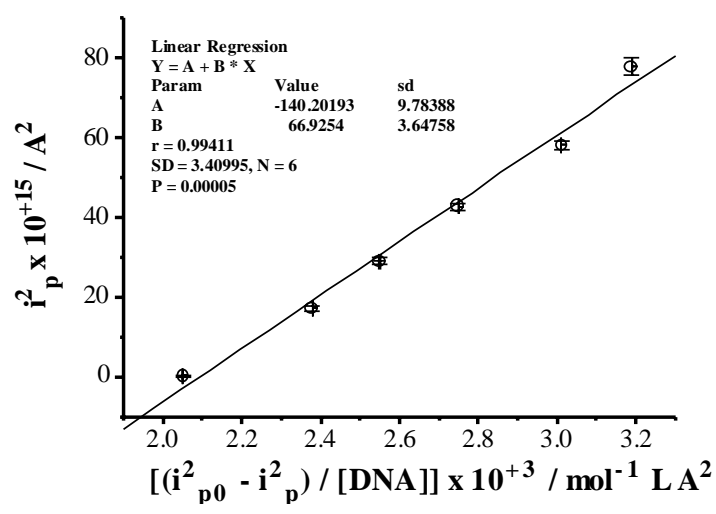

Figure 6. The plot $i_{\mathrm{p}}{ }^{2}$ vs. $\frac{\left(\mathrm{i}_{\mathrm{p} 0}^{2}-\mathrm{i}_{\mathrm{p}}{ }^{2}\right)}{[\mathrm{DNA}]}$ used to calculate the dissociation constant of $\mathrm{Zn}^{2+-}$ lambda phage DNA complex.

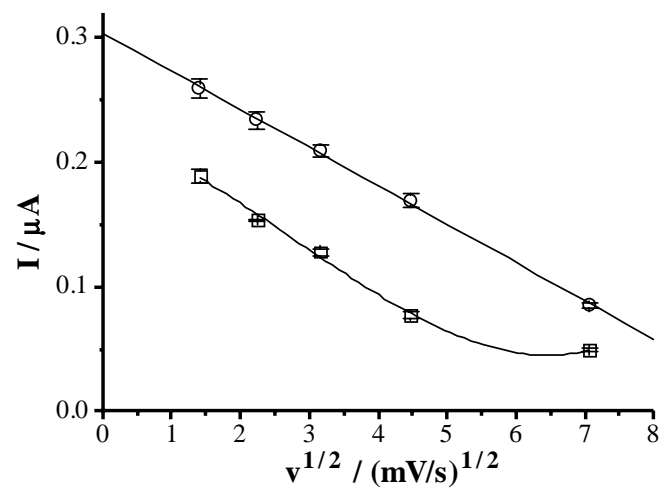

Figure 7. Variation of peak current of $1.5 \mathrm{~mL}$ of $1.5 \times 10^{-8} \mathrm{~mol} \mathrm{~L}^{-1}$ $\mathrm{Zn}^{2+}$ in $20 \mathrm{~mL}$ of $0.1 \mathrm{~mol} \mathrm{~L}^{-1} \mathrm{KNO}_{3}$ with square root of the scan rate in absence $(\mathrm{O})$ and presence $(\square)$ of $2.8 \times 10^{-11} \mathrm{~mol} \mathrm{~L}^{-1}$ lambda phage DNA. $\mathrm{E}_{\mathrm{i}}=-0.2 \mathrm{~V}, \mathrm{E}_{\mathrm{w}}=-1.6 \mathrm{~V}, 2 \mathrm{mV} \mathrm{s}^{-1} \leq \mathrm{v} \leq 50 \mathrm{mV} \mathrm{s}^{-1}$, working electrode: HMDE.

\section{Discussion}

Zinc regulates the gene expression machinery. It affects the structure of chromatin, the template function of its DNA, the activity of numerous transcription factors and of DNA and RNA polymerases ${ }^{1,2}$. In order to understand why $\mathrm{Zn}^{2+}$ ions in particular are required, many researchers have studied the interactions of zinc and DNA by several techniques $16,19,31-32$. In these studies an attempt was made to understand specific changes of DNA secondary structure induced by zinc ion binding. $\mathrm{Zn}^{2+}$ ions, as other transition metals bind preferentially to the phosphate sugar backbone, but they can also interact with bases (guanines and cytosines) after heat desnaturation. $\mathrm{Zn}^{2+}$ decreases the melting temperature of the DNA molecule at high $\mathrm{Zn}^{2+}$ : DNA-P ratio and aids the reformation of the DNA double helix upon cooling. These effects have been attributed to the formation of metal bridges between complementary bases (GC pair) of opposite strands in the unwound state and were found to be directly and reversely related to GC content of the DNA. The $\mathrm{Zn}^{2+}$ : DNA-P ratio used in our experiments was one, so that we can infer that zinc ions are stabilizing the duplex (GC pairs) by their electrostatic interaction with the negative phosphate groups of lambda phage DNA.

The methodology developed in this work allowed determination of stoichiometry, dissociation constant and a possible mechanism of the interaction between $\mathrm{Zn}^{2+}$ and lambda phage DNA. The stoichiometry values obtained by differential pulse voltammetry (23:1) and cyclic voltammetry (22:1) are very close. However, considering the size of the DNA molecule under investigation and the potential number of phosphate groups available, one could expect a higher number of binding sites for $\mathrm{Zn}^{2+}$. Although on $\mathrm{Zn}^{2+}$ : DNA stoichiometries are surprisingly low, one has to take into account stereochemistry problems due to overfolding of such a large molecule under the experimental conditions used. These results will be checked by further voltammetric experiments with a synthetic oligonucleotide. Using this smaller DNA, it will be possible to make an accurate measure of the stoichiometry and the binding sites of the reaction. The low $\mathrm{K}_{\mathrm{d}}$ values found for the complex $\mathrm{Zn}^{2+}$ - lambda phage DNA using differential pulse voltammetry $\left(\mathrm{K}_{\mathrm{d}}=3.44 \times 10^{-11} \mathrm{~mol} \mathrm{~L}^{-}\right.$ $\left.{ }^{1}\right)$ and cyclic voltammetry $\left(\mathrm{K}_{\mathrm{d}}=6.69 \times 10^{-11} \mathrm{~mol} \mathrm{~L}^{-1}\right)$ are very close and imply that $\mathrm{Zn}^{2+}$ ions are indispensable for catalytic function and structural stability of zinc enzymes which participate in the replication, degradation and translation of genetic material of all species. Moreover, they are probably interacting not only with the active site of the enzyme during these processes, as already well-known in the literature ${ }^{1,2}$, but also with DNA.

The differential pulse voltammograms in figure 1 show that the addition of lambda phage DNA to the electrochemical cell containing $1.0 \mathrm{~mL}$ of $1.5 \times 10^{-8} \mathrm{~mol} \mathrm{~L}^{-1}$ $\mathrm{Zn}^{2+}$ did not shift the reduction peak of zinc $\left(\mathrm{E}_{\mathrm{p}}=\right.$ constant), in addition to that, this peak disappears after the complete complexation of $\mathrm{Zn}^{2+}$. We can also notice that the quantity of charge is constant (the width of the reduction peak of zinc at $h / 2$ is not changing with the addition of DNA). These two evidences suggest that $\mathrm{Zn}^{2+}$ ion is the chemical species which is arriving on the $\mathrm{Hg}$ surface to undergo reduction. Curves I vs. $v^{1 / 2}$ in Figure 7 show that the oxidation-reduction process of zinc is no longer controlled by diffusion in the presence of lambda phage DNA. It is known that DNA adsorbs onto mercury electrode in the potential range of about 0 to $-1.3 \mathrm{~V}$ at neutral $\mathrm{pH}$ and moderate ionic strength ${ }^{33}$, so that we can infer that lambda phage DNA is mediating the charge transfer of bulk $\mathrm{Zn}^{2+}$ ions $\left(\mathrm{Zn}^{2+}(\mathrm{b})\right)$ through its adsorption on mercury surface. 


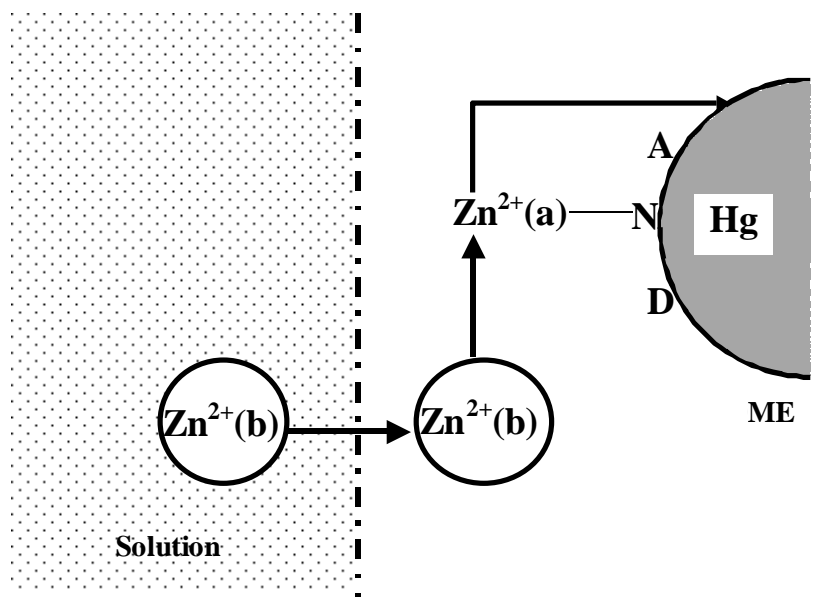

Figure 8. Mechanism proposed to explain the oxidation-reduction process of $\mathrm{Zn}^{2+}$ in the presence of lambda phage DNA. b = bulk, $\mathrm{a}=$ bounded.

Unfortunately, the mechanism of this process is not known. Probably, the bulk $\mathrm{Zn}^{2+}$ ions $\left(\mathrm{Zn}^{2+}(\mathrm{b})\right)$ are replacing the zinc bounded to lambda phage DNA $\left(\mathrm{Zn}^{2+}(\mathrm{a})\right)$, thereupon, this $\mathrm{Zn}^{2+}$ (a) is released to $\mathrm{Hg}$ surface to undergo reduction (Figure 8).

\section{Conclusion}

Conductimetry, equilibrium dialysis, UV-Vis spectroscopy and X-ray crystallography have been used to study metal-nucleic acid interactions since 1960 . However, they present some experimental difficulties or limitations which make them not suitable for measurement of metal-ion binding to DNA. The electrochemical methods used in the present work overcame these difficulties. The results obtained in the study of $\mathrm{Zn}^{2+}$-DNA interaction by differential pulse polarography and cyclic voltammetry pointed out the possibilities that voltammetric techniques now offer for determining quantitative data of metal-nucleic acid interactions. Dissociation constant and stoichiometry values and also a possible mechanism of $\mathrm{Zn}^{2+}$-DNA interaction were determined successfully by using a simple and rapid voltammetric procedure. A quantitative knowledge of the degree and strength of $\mathrm{Zn}^{2+}$ binding to lambda phage DNA will be helpful in understanding the cleavage of deoxyribonucleic acids.

\section{Acknowledgments}

The authors wish to express their gratitude to Professors A. C. Barbosa and L. Morhy for providing certain facilities, to Dr. Daniel Rigden for his help in revising the English text and to CNPq, CAPES, FAPDF for financial support.

\section{References}

1. Blackburn, G. M.; Gait, M. J. Nucleic Acids in Chemistry and Biology; Oxford University Press; New York, 1996.

2. Hetch, S. M. Bioorganic Chemistry: Nucleic Acids; Oxford University Press; New York, 1996.

3. Shack, J.; Jenkins, R. J.; Trompsett, J. M. J. Biol. Chem. 1953, 203, 373.

4. Felsenfeld, G.; Huang, S. L. Biochim. Biophys. Acta 1961, 51, 19.

5. Mathieson, A. R.; Olayemi, J. Y. Arch. Biochem. Biophys. 1975, 169, 237.

6. Lyons, J. W.; Kotin, L. J. Am. Chem. Soc. 1964, 86, 3634.

7. Eichhorn, G. L.; Clark, P.; Becker, E. D. Biochemistry 1966, 5, 245.

8. Bryan, S. E.; Frieden, E. Biochemistry 1967, 6, 2728.

9. Burks, P. P. Diss. Abstr. Int. B 1971, 31, 5228.

10. Zimmer, C. H.; Luck, G.; Fritzsche, H.; Triebel, H. Biopolymers 1971, 10, 441.

11. Sorokin, V. A. Biophysics 1994, 39, 1041.

12. Hua, E.;Wang, H.; Yang, P.; Yang, B. Polyhedron 1996, 15, 2067.

13. Sorokin, V.A.; Valeev, V.A.; Gladchenko, G. O.; Sysa, I. V.; Blagoi, Y. P.; Volchok, I. V. J. Inorg. Biochem. 1996, 63, 79.

14. Yamame, T.; Davidson, N. J. Am. Chem. Soc. 1961, 83, 2599.

15. Gulanowski, B.; Swiatek, J.; Kozlowski, H. J. Inorg. Biochem. 1992, 48, 289.

16. Zimmer, C. H.; Luck, G.; Triebel, H. Bioploymers 1974, 13, 425.

17. Wiberg, J. S.; Neuman, W. F. Arch. Biochem. Biophys. 1957, 72, 66 .

18. Shapiro, J. T.; Stannard, B. S.; Felsenfeld, G. Biochemistry 1969, 8, 3233.

19. Banerjee, K. C.; Perkins, D. J. Biochim. Biophys. Acta 1962, 61, 1.

20. Carrabine, J. A. Diss. Abstr. Int. B 1970, 31, 3230 .

21. Berman, H. M.; Shieh, H.-S. In Topics in Nucleic Acid Structure; Neidle, S., Ed.; Wiley; New York, 1981, p. 17.

22. Sarma, R. H.; Dhingra, M. M. In Topics in Nucleic Acid Structure; Neidle, S., Ed.; Wiley; New York, 1981, p. 33.

23. Swaminathan, V.; Sundaralingam, M. Crit. Rev. Biochem. 1979, 6, 245.

24. Kalsbeck, W.; Thorp, H. J. Am. Chem. Soc. 1993, $115,7146$. 
25. Carter, M. T.; Rodriguez, M.; Bard, A. J. J. Am. Chem. Soc. 1989, 111, 8901.

26. Bach, D.; Miller, I. R. Biopolymers 1967, 5, 161.

27. Elzanowska, H.; Van de Dande, J. H. Bioelectrochem. Bioenerg. 1988, 19, 441.

28. Fasman, G. D. Handbook of Biochemistry and Molecular Biology; $3^{\text {rd }}$ ed.; CRC Press; Cleveland, $\mathrm{OH}$, 1975, p. 589.
29. Niu, J.; Cheng, G.; Dong, S. Electrochim. Acta 1994, 39, 2455.

30. Van Benschoten, J. J.; Lewis, J.Y;; Heineman, W. R.; Roston, D. A.; Kissinger, P. T. J. Chem. Educ. 1983, 60, 772.

31. Eichhorn, G. L.; Butzow, J. J.; Clark, P.; Tarien, E. Biopolymers 1967, 5, 283.

32. Jia, X. Diss. Abstr. Int. B 1991, 52, 3058.

33. Krznaric, D.; Cosovic, B.Anal. Biochem. 1986, 156, 454.

Received: May31, 1999 